\title{
Dokuzuncu sınıf öğrencilerinin merkezi eğilim ve yayılım ölçüleri konusundaki informel istatistiksel çıarsamaları üzerine bir inceleme
}

\author{
Hatice AKKOÇ $\left.{ }^{*}\right]$ \\ Abdullah Selman SELÇUK ${ }^{[*]}$
}

\begin{abstract}
Öz
İstatistiksel çıkarsama verilerin yorumlanmasını gerektiren bir süreçtir. Formel olarak istatistik öğretimi almadan istatistiksel çıkarsama yapılabilmenin önemli olduğu göz önüne alındığında, bu durumun nasıl olduğunun ortaya konması önem arz etmektedir. Buradan hareketle araştırmanın amacı, ortaöğretime yeni başlamış dokuzuncu sınıf öğrencilerinin merkezi eğilim ve yayılım ölçüleri konusundaki informel istatistiksel çıkarsamalarının nasıl olduğunu ortaya koymaktır. Bu amaç doğrultusunda araştırmada nicel araştırma yöntemlerinden tarama yöntemi kullanılmıştır. Dokuzuncu sınıfa yeni başlamış 34 öğrenciye açık uçlu sorulardan oluşan İnformel İstatistiksel Çıkarsama Tespit Testi (İICTTT) uygulanmıştır. Öğrencilerin informel istatistiksel çıkarsamalarının nasıl olduğu belirlenirken Makar ve Rubin’in (2009) ortaya koyduğu informel istatistiksel çıarsama teorik çerçevesi kullanılmıştır. Araştırma bulguları öğrencilerin çoğunluğunun merkezi eğilim ve yayılım ölçüleri konusunda informel istatistiksel çıkarsama yapabildiklerini göstermektedir. Ayrıca araştırmada öğrencilerin formel kavramları informel referanslarla kullanabildiği görülmüștür.
\end{abstract}

Anahtar kelimeler: Merkezi eğilim ve yayılım ölçüleri, informel çıkarımsal muhakeme, informel istatistiksel çıarsama.

\section{Examination of 9th-grade students' informal statistical inferences with regard to measures of central tendency and variability}

\footnotetext{
Abstract

Statistical inference is a process of interpretation of data. Considering the importance of making a statistical inference without receiving any formal instruction on statistics, revealing the ways

* Doç. Dr., Marmara Üniversitesi, Atatürk Eğitim Fakültesi, Matematik ve Fen Bilimleri Eğitimi Bölümü,

** Öğretmen, Sultangazi Cumhuriyet Anadolu Lisesi, seselcuk@windowslive.com
} hakkoc@marmara.edu.tr 
in which these processes occur is vital. Therefore, the aim of this study is to investigate how 9thgrade students make informal statistical inference in the context of central tendency and measures of variability. Informal Statistical Inference Test (İIÇTT) which includes open-ended questions was administered to 34 students who have just begun 9th grade. Data obtained from students' written responses were analyzed using Makar and Rubin's (2009) theoretical framework of informal statistical inference. Findings indicated that the majority of students can make informal statistical inference about measures of central tendency and variability. It was also found that students can use formal concepts with informal references.

Keywords: Measures of central tendency and variability, informal inferential reasoning, informal statistical inference.

\section{Giriş}

İstatistik okuryazarlığı günlük hayatımızın çeşitli alanlarında karşımıza çıkan durumları yorumlamak için önemli bir beceridir. Medyada karşımıza çıkan istatistik verilerini ve grafiklerini yorumlayabilmek istatistik okuryazarlı̆̆ 1 ile ilişkilidir. Bu konunun önemi Franklin vd.nin (2007) yayımladıkları GAISE raporu gibi uluslararası raporlarda da ön plana çıkmaktadır. Her lise mezununun vatandaşlık meseleleri, aile gereksinimleri ile başa çıkabilmesi ve sağlıklı, mutlu ve üretken bir yaşam sürdürebilmesi için istatistiksel muhakeme yapması gerektiği bu raporda vurgulanmaktadir.

Ülkemizde son yıllarda matematik öğretim programlarında sık sık değişiklikler meydana gelmektedir. Bu değişimlerden biri de “veri” öğrenme alanı altında temel istatistik kavramlarının öğretim programına dahil edilmesi noktasında yaşanmaktadır. İstatistik 2004 yılında matematik öğretim programında yapılan değişiklikle ilkokul 1. sınıf seviyesinden itibaren "veri öğrenme alanı” altında öğretilmeye başlanmıştır (MEB, 2004). 2015 yılında İlkokul Matematik Dersi (1, 2, 3 ve 4. Sınıflar) Öğretim Programı yayımlanarak “veri” öğrenme alanında istatistik öğretiminin devam etmesi planlanmıştır (MEB, 2015). Öğrencilerin ortaokul seviyesinde istatistik konuları ile karşılaşmaları ise 2005 yılında yapılan düzenleme ile gerçekleşmiştir (MEB, 2005). Öğretim programında "Olasılık ve istatistik" öğrenme alanında yer bulan istatistik konuları, 2013 yılında yayımlanan "Ortaokul Matematik Dersi (5, 6, 7 ve 8. Sınıflar) Öğretim Programı” içerisinde "veri işleme" alanında yer almıştır (MEB, 2005; MEB, 2013). Ortaöğretim düzeyinde ise istatistik, 2013 yılında yapılan değişiklikle dokuzuncu sınıf seviyesinden itibaren "veri, sayma ve olasılık” öğrenme alanı altında öğretilmeye başlanmıştır (MEB, 2013). 2013 yılında yayımlanan Ortaöğretim Matematik Dersi (9, 10, 11 ve 12. Sınıflar) Öğretim Programı’nda öğrenciler istatistik ile dokuzuncu sınıfın son ünitesinde karşılaşmaktadırlar. İlk olarak 2013-2014 öğretim yılında dokuzuncu sınıflarda uygulanmaya başlanan öğretim programında öğrencilerin informel durumlarla karşılaşması ve bu informel durumdan formel bir matematiksel yapıya ulaşmaları amaçlanmaktadır (MEB, 2013).

Matematik öğretim programlarımızda istatistik öğretiminde vurgulanan noktalar genel olarak; veri, verinin yorumlanması, verinin grafiklerle temsil edilmesi, merkezi eğilim ve 
yayılım ölçülerinin hesaplanması ve verileri anlamlandırma adına merkezi eğilim ve yayılım ölçülerinin yorumlanmasıdır. Ayrıca öğrencilerin gerçek yaşam durumları üzerinde muhakeme yapabilmelerinin sağlanması amaçlanmıştır (MEB, 2004; MEB, 2005; MEB, 2013; MEB, 2015).

Yukarıda belirtildiği üzere gerek ülkemizde gerekse de diğer ülkelerde istatistik konularının öğretim programlarında yer alması ile istatistik öğretiminin nasıl yapılması gerektiği de gündeme gelmiştir. Ortaokul ve lise düzeyinde istatistik öğretimi üzerine Amerika Birleşik Devletleri’nde hazırlanan GAISE raporunda istatistik öğretiminin üç seviyesi olduğundan bahsedilmektedir ve bu üç seviyenin her birinde de istatistiksel çıkarsamanın önemi vurgulanmaktadır (Franklin vd., 2007). Bunun yanında bu raporda, öğrencilerin karşılaştıkları soruları cevaplarken informel çıkarımlar yapabilmelerinin öğretilmesi gerektiği savunulmaktadır. Öğrencilerin çıkarımsal muhakemelerinin geliştirilmesinin öğrencilerin anlamlı öğrenme oluşturabilmelerindeki derin potansiyeli olduğu belirtilmektedir (Franklin vd., 2007). İstatistiksel çıkarsama, çıkarımsal muhakeme ve informel çıarım kavramlarının bir arada düşünülmesi informel istatistiksel çıkarsama kavramını karşımıza çıkarmaktadır.

İnformel istatistiksel çıkarsamayı birçok araştırmacı açıklamaya çalışmıştır (Gil, Ben-Zvi ve Apel, 2007; Pfannkuch, 2006; Rossman, 2008). İnformel istatistiksel çıkarsamanın tanımında bir belirsizlik göze çarpmakla birlikte, bir araştırma sonucunda verilere dayanarak olasıllksal bir genelleme ortaya koymak olarak tanımlanabilir (Garfield, Le, Zieffler ve Ben-Zvi, 2014). Bu tanıma paralel olarak Makar ve Rubin (2009), verilere dayanarak olasilıksal olarak ifade edilmiş genellemeleri test etmenin de istatistiksel çıkarsama içinde olduğunu belirtmiştir. Buradan hareketle genelleme ortaya konulmasının da genellemenin doğruluğunun test edilmesinin de informel istatistiksel çıkarsama olarak değerlendirildiği söylenebilir. Sonuç olarak, informel istatistiksel çıkarsama kavramı içinde iki bileşenden bahsedilebilir: sonuç çıkarma ve bu sonuca ulaşırken gerçekleşen süreçler. Bu ifadeyi destekler nitelikte olarak Makar ve Rubin (2009), istatistiksel çıkarsamanın sonuç ortaya koymayı gerektiren bir süreç olduğunu belirtmişlerdir.

Rossman (2007), informel istatistiksel çıkarsamayı, gözlenen veriler için bir açılama ortaya konulması süreci olarak ifade etmiş ve bu süreçte gerekçelendirmenin formal yöntemler yardımıyla değil argüman yoluyla yapıldığını belirtmiştir. İnformel istatistiksel çıkarsama, verilerden elde edilen genellemelerin test edilmesiyle olur ve bu genellemelerin oluşturulmasında standart istatistiksel süreçlerin kullanılması zorunlu değildir (Makar ve Rubin, 2009). Başka bir deyişle, verilerden yola çıkarak bir genellemeye ulaşmak, formel yolla olabileceği gibi informel yolla da olabilir. İnformel istatistiksel çıkarsamanın bir başka açılamasını yapan Pfannkuch (2007), informel istatistiksel çıkarsamayı verilerin dağılımına bakarak, muhakeme ve karşılaştırmaya dayalı bir şekilde verilerden sonuç çıkarma olarak tanımlamıştır. Buradaki ifadeden hareketle informel istatistiksel çıkarsama, muhakeme süreçleri sonunda sonuca ulaşmaktır denilebilir.

İnformel istatistiksel çıkarsamanın yanında literatürde geçen bir diğer kavram ise informel çıarımsal muhakemedir (Garfield vd., 2014; Makar ve Rubin, 2009; Makar vd., 2011; Zieffler vd., 2008). Birbirlerine çok benzeyen bu iki kavramın net olarak ne anlama geldiğinin belirlenemediğini belirten Zieffler vd. (2008), informel çlkarımsal muhakemeyi; "öğrencilerin 
gözlemledikleri örneklemlere dayalı olarak bilinmeyen evrenle ilgili yaptıkları çıkarımları desteklemek için argüman oluşturmada informal istatistiksel bilgilerini kullandıkları yol” olarak ifade etmiştir (s. 44). Bir başka tanımda informel çıkarımsal muhakeme, verilerin tamamının özellikleri ile ilgili fikirleri içeren muhakeme olarak açıklanmıştır (Rubin, Hammerman ve Konold, 2006).

İnformal çıkarımsal muhakeme verilerin ötesine giden ve ampirik kanıt içeren belirsizlikler için sonuç oluşturmada gerçekleştirilen bilişsel faaliyetlerdir (Gil, Ben-Zvi ve Apel, 2008). Aynı zamanda bilişsel faaliyetler sonuç oluşturma amacıyla gerçekleştirilir. Bu yönüyle bakıldığında da informel istatistiksel çıkarsama kavramına ulaşmak mümkündür. Dolayısıyla informel çıkarımsal muhakeme ve informel istatistiksel çıkarsamanın birbiriyle kaynaşmış kavramlar olduğunu söylemek yanlış olmaz.

İnformel çıkarımsal muhakeme ve informel istatistiksel çıkarsama kavramına genel bir bakış yapıldığında; informel çıkarımsal muhakemenin sürece odaklandığı, informel istatistiksel çıkarsamanın ise sonuca odaklandığı söylenilebilir. Bununla birlikte iki kavramda "çıkarım" ifadesinin yer alması, bu kavramların birbirinden net çizgilerle ayrılmadığını da göstermektedir. Nitekim “çıkarım” kavramının zor bir kavram olduğunu belirten Erickson (akt. Makar ve Rubin, 2009), çıkarsamayı profesyonel araştırmacıların bile uygunsuz kullanabildiğini belirtmiştir. Bu sebeple informel istatistiksel çıkarsama ve informel çıkarımsal muhakeme kavramları birçok araştırmada bir arada kullanılmıştır (Ben-Zvi vd., 2007; Makar vd., 2011; Makar ve Rubin, 2009; Pfannkuch, 2006; Rossman, 2008; Zieffler vd., 2008). Bu çalışmada öğrencilerin muhakeme süreçleri sonucunda yaptıkları informel istatistiksel çıkarsamalarına odaklanıldı̆̆ından informel istatistiksel çıkarsama kavramı tercih edilmiştir.

\section{Teorik çerçeve}

Verilerden yola çıkarak genelleme yapabilmek istatistiksel çıkarsama sürecinde önemli bir yere sahiptir (Franklin vd., 2007). Verileri kullanarak istatistiksel çıkarsamayı desteklemeyi, verilerin ötesine genelleme yapmayı ve istatistiksel çıkarsamada gömülü olan belirsizliği olasılıksal dil ile ifade etmeyi informel istatistiksel çıkarsamanın bileşeni olarak kabul eden Makar ve Rubin (2009), informel istatistiksel çıkarsamanın öğrenci anlayışını derinleştirmede önemli potansiyele sahip olduğunu ifade etmişlerdir. Dokuzuncu sınıf öğrencilerinin informel istatistiksel çıkarsamalarının nasıl olduğunu ortaya koyma amacında olan bu çalışmanın dayandığg teorik çerçeve, Makar ve Rubin’in (2009) ortaya koyduğu informel istatistiksel çıkarsama teorik çerçevesidir.

\section{Informel istatistiksel çıkarsamanın bileşenleri}

Makar ve Rubin’e (2009) göre informel istatistiksel çıkarsama için kritik olan kavramlar vardır. Bu kavramlar şunlardır:

- Belirsizlik ve değişkenlik kavramı

- Grup (veri seti) hakkındaki genellemeleri kullanarak (veri setindeki değerleri birbirinden bağımsız olarak ele almak yerine) verinin özetlenmesi kavramına dayanma 
- Eldeki verilerin ötesine giden mekanizmanın veya eğilimin kabulü

- Verileri amaçlı bir şekilde kullanarak yapılan muhakemelerde delillere dayanma

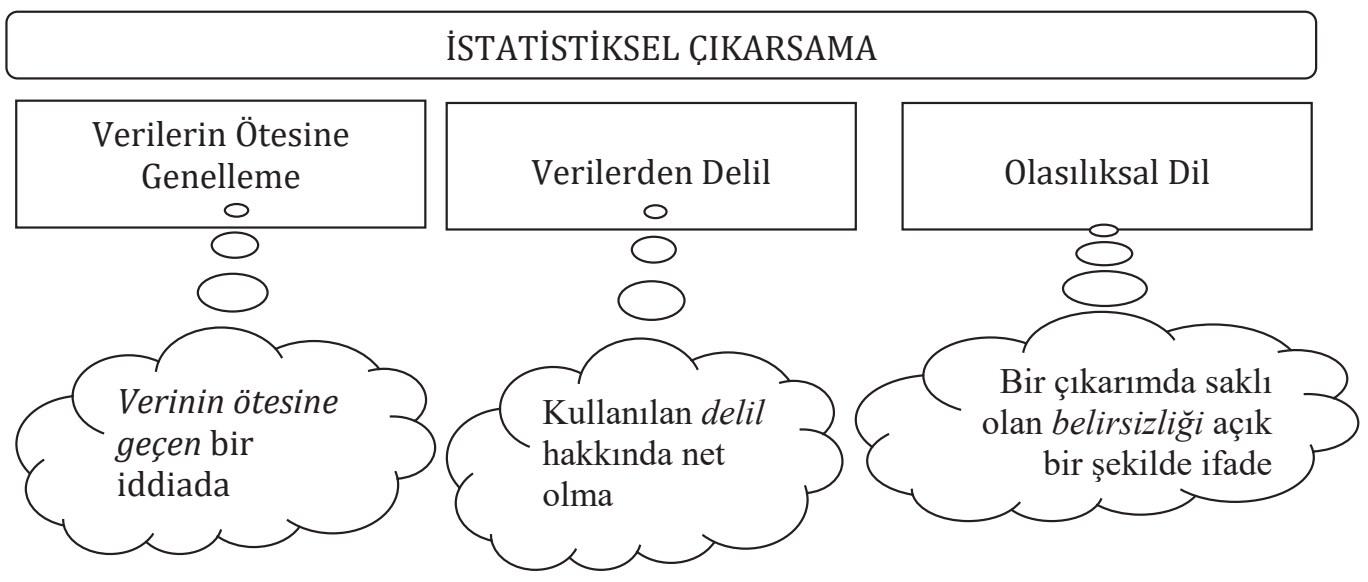

Şekil I. İstatistiksel çıkarma için teorik çerçeve (Makar ve Rubin, 2009, s. 85).

Makar ve Rubin (2009) bu kritik kavramlardan yola çıkarak informel istatistiksel çıkarsamada üç bileşen ortaya koymuştur: verilerin ötesine genelleme, verilerden delil ve olasılıksal dil (Şekil 1). Yukarıdaki kavramların her birisi en az bir bileşeni açıklamakta kullanılmaktadır. Bu bileşenler aşağıda ayrıntılı olarak verilmiştir.

\section{Verilerin ötesine genelleme}

Verilerin ötesine genelleme bileşeni istatistiksel çıkarsama için kritik olan kavramlardan iki tanesinden yola çlkılarak oluşturulmuştur. Bu kritik kavramlardan birincisi, grup (veri seti) hakkındaki genellemeleri kullanarak (veri setindeki değerleri birbirinden bağımsız olarak ele almak yerine) verinin özetlenmesi kavramına dayanmaktadır (Makar ve Rubin, 2009). İnformel istatistiksel çıkarsama sürecinde veri setindeki değerlerin ayrı ayrı ele alınması yerine tüm verileri özetleme durumu söz konusudur. Bu duruma örnek olarak merkezi eğilim ölçülerinden aritmetik ortalama verilebilir (Makar ve Rubin, 2009). Aritmetik ortalama, veri setindeki tüm değerler kullanılarak hesaplanan ve grubun merkezi eğilimini ifade eden bir değerdir. Bununla birlikte, aritmetik ortalama betimsel istatistik içerisinde yer aldığından verilerin ötesine geçememektedir. İstatistiksel çıkarsamada ise verilerin ötesine genelleme bileşeni, veri setindeki değerlerin ötesine geçerek verilerin özetlenmesini ifade eder. Verilerin ötesine genelleme bileşeni tam bu noktada, eldeki verilerin ötesine giden mekanizmanın veya eğilimin kabulü kritik kavramından beslenmektedir. Verilerin ötesine genelleme bileşeninde eldeki verilerin çok daha ötesine gidilerek evren için iddiada bulunmak söz konusudur (Makar ve Rubin, 2009). Bu ise yordamsal (çıkarımsal) istatistik tekniklerini gerektirir. Sonuç olarak verilerin ötesine genelleme 
bileşeni informel istatistiksel çıkarsama teorik çerçevesinde, veri setindeki değerlerin durumunu verilerin ötesine giden eğilim veya mekanizmayı kabul ederek özetlemeyi ifade eder.

\section{Verilerden delil}

Verileri amaçl bir şekilde kullanarak yapılan muhakemelerde delillere dayanma kritik kavramının oluşturduğu bileşen olan verilerden delil, istatistiksel çıkarsamada verilerin delil olarak sunulmasını ifade eder. Bir şeyin delil sayılabilmesi için, ortaya konulduğu zaman herkesçe kabul edilmesi gerekmektedir. Kullanılan delilin açık ve net olması gerekmektedir (Makar ve Rubin, 2009).

\section{Olasılıksal dil}

İnformel istatistiksel çıkarsama için kritik olan bir diğer kavram ise belirsizlik ve değişkenlik kavramıdır. İnformel istatistiksel çıkarsamanın içinde olan belirsizliğin kesin olmayan ifadelerle çıkarsamanın içinde belirtilmesi olasılıksal dil bileşenini ifade eder. Yapılan çıkarsamalar için çoğu zaman değişkenlik ve belirsizlik söz konusudur. Olasılıksal dil sürecinde bu değişkenlik ve belirsizlik düzgün bir şekilde ifade edilir. Örneğin 8 yaşındaki bir grupta bulunan çocukların boy uzunluklarının verildiği bir durumu düşünelim. Bu grubun tipik boy uzunluğunu tahmin ederken öğrencilerin boy uzunluğunun 130-138 cm arasında olabileceğini söylemeleri olasılıksal dil bileşenine uygun bir ifadedir. Olasılıksal dil kullanımında kesin ifadelerden kaçınılması esastır (Makar ve Rubin, 2009).

\section{Teorik çerçeve ışığında araştırma soruları}

İstatistik öğretiminde öğrencilerde muhakeme becerilerinin geliştirilmesi verilerin anlamının öğrenciler tarafından anlaşılabilmesi için önem taşımaktadır (Aliaga vd., 2012; Franklin vd., 2007; MEB, 2013). Öğrenciler yeni görecekleri konu ile ilgili formel bilgileri elde etmeden de muhakeme ve yorumlama yapabilirler (Makar, 2013). Dolayısıyla dokuzuncu sınıfa yeni başlamış öğrencilerin henüz ortaöğretim düzeyinde istatistik öğretimi almadan da informel istatistiksel çıkarsama yapabilecekleri savunulabilir. Bununla birlikte bu öğrenciler ilköğretim 5. sinıfta "veri öğrenme alanı" içindeki "aritmetik ortalama alt öğrenme alanı” altında aritmetik ortalamayı ve 7. sınıfta "olasılık ve istatistik" öğrenme alanı altında ortanca, tepe değer ve çeyrekler açılığı kavramlarını öğrenmişlerdir (MEB, 2004; MEB, 2005). Bu açıdan bakıldığında formel bilgiler öğretilmeden öğrencilerin informel çıkarsamalarda bulunmalarının önemli olduğu da dikkate alınırsa, dokuzuncu sınıfa yeni başlamış öğrencilerin informel istatistiksel çıkarsamalarının tespit edilmesi önem arz etmektedir (MEB, 2013). Ayrıca formel eğitimden önce öğrencilerin muhakeme sürecinde informel çıkarsama yapmaları formel eğitimleri için önemlidir (Makar ve Rubin, 2009; Makar, Bakker ve Ben-Zvi, 2011; Zieffler, Garfield, Delmas ve Reading, 2008). $\mathrm{Bu}$ önem doğrultusunda bu çalışmanın amacı, ortaöğretime yeni başlamış dokuzuncu sınıf öğrencilerinin informel istatistiksel çıkarsamalarının nasıl olduğunu ortaya koymaktır.

Makar ve Rubin'in (2009) informel istatistiksel çıkarsama için ortaya koyduğu teorik çerçeve altında, dokuzuncu sınıf öğrencilerinin informel istatistiksel çıkarsamalarının nasıl olduğunu 
ortaya koyma amacında olan bu çalışmanın araştırma sorusu ve bu sorunun alt soruları şu şekildedir:

Dokuzuncu sınıf öğrencilerinin merkezi eğilim ve yayılma ölçüleri konusunda informel istatistiksel çıkarsamaları nasıldır?

a. Dokuzuncu sınıf öğrencilerinin öğrenciler merkezi eğilim ve yayılım ölçüleri konusunda verilerin ötesine genelleme bileşeninde informel istatistiksel çıkarsamaları nasıldır?

b. Dokuzuncu sınıf öğrencilerinin öğrenciler merkezi eğilim ve yayılım ölçüleri konusunda verilerden delil bileşeninde informel istatistiksel çıkarsamaları nasıldır?

c. Dokuzuncu sınıf öğrencilerinin öğrenciler merkezi eğilim ve yayılım ölçüleri konusunda olasılıksal dil bileşeninde informel istatistiksel çıkarsamaları nasıldır?

\section{Yöntem}

\section{Araştırma modeli}

Dokuzuncu sınıf öğrencilerinin informel istatistiksel çıkarsamalarının nasıl olduğunu ortaya koyma amacında olan bu çalışmada nicel araştırma yöntemlerinden tarama yöntemi kullanılmıştır. Tarama yöntemi belli bir zamanda bireylerin, grupların, metotların veya materyallerin; tanmlanması, betimlenmesi, karşılaştırılması, sınıflandırılması, analiz edilmesi ve yorumlanması amacıyla veri toplar (Cohen, Manion ve Morrison, 2007). Bu çalışmada dokuzuncu sınıf öğrencilerinin informel istatistiksel çıkarsamaları, geliştirilen informel çıkarsama tespit testi yardımıyla belirlenerek ortaya konulmuş ve birbirine benzer nitelikte olan informel istatistiksel çıkarsamalar teorik çerçevesi ışığında sınıflandırılmıştır. Bu sayede ortaöğretime yeni başlamış dokuzuncu sınıf öğrencilerinin informel istatistiksel çıkarsamalarına ait bir resim ortaya konulmaya çalışılmıştır.

\section{Evren ve örneklem}

Çalışmanın örneklemini 2014-2015 öğretim yılında İstanbul Sultangazi ilçesindeki bir anadolu lisesinde öğrenim görmekte olan 34 dokuzuncu sınıf öğrencisi oluşturmaktadır. Örneklem, uygun örnekleme yöntemi yardımıyla belirlenmiştir. Uygun örnekleme yönteminde zaman, para ve işgücü kaybını önlemek temel amaçtır (Balcı, 2011; Büyüköztürk vd., 2013). En ulaşılabilir grubun belirlenmesi üzerine kurulu bu örnekleme yöntemi yardımıyla araştırmacının çalıştığ kurumun dokuzuncu sınıf öğrencilerinden örneklem oluşturulmuştur (Büyüköztürk vd., 2013).

\section{Veri toplama araçları}

Çalışmada veri toplama aracı olarak informel istatistiksel çıkarsama tespit testi kullanılmıştır. İnformel istatistiksel çıkarsama tespit testi (İIÇTT), toplam dört sorudan oluşmaktadır. Testin üç sorusu öğrencilerin informel istatistiksel çıkarsamalarını belirlemek için Park’’n (2012) geliştirdiği testten; diğer sorusu ise öğrencilerin istatistik düşünme düzeylerini belirleme amacıyla Koparan ve Güven'in (2013) oluşturduğu testten alınmıştır. Kullanılan tüm soruların 
geçerlik ve güvenirlik çalışmaları soruların geliştirilmesi aşamasında Koparan ve Güven (2013) ve Park (2012) tarafından yapıldığından çalışmada bu sorular için geçerlik ve güvenirlik çalışması yapılmamıştır.

Merkezi eğilim ve yayılım ölçüleri konusu ile ilgili sorulardan oluşan İIÇTT, bu konu ile ilgili sorularda öğrencilerin informel istatistiksel çıkarsamalarını ortaya koymayı amaçlamaktadır. Testin geliştirilmesi aşamasında pilot çalışma yapılmış ve bu pilot çalışma sonrası sorular revize edilmiştir. Ayrıca pilot çalışmada öğrencilerin hiç biri tarafından cevap verilemeyen bir soru İIÇTT'den çıkartılmıştır.

Tablo 1'de İICÇTT'yi oluşturan soruların ilgili olduğu informel istatistiksel çıkarsama bileşeni gösterilmektedir.

Tablo 1

IIIÇTT ile Teorik Çerçeve Ilişkisi

\begin{tabular}{|c|c|c|c|}
\hline \multirow{2}{*}{} & \multicolumn{3}{|c|}{ İnformel İstatistiksel Çıkarsama Teorik Çercevesi } \\
\cline { 2 - 4 } & Verilerin Ötesine Genelleme & Verilerden Delil & Olasılıksal Dil \\
\hline Soru 1 & $\checkmark$ & - & $\checkmark$ \\
\hline Soru 2 & $\checkmark$ & $\checkmark$ & - \\
\hline Soru 3 & - & $\checkmark$ & - \\
\hline Soru 4 & - & $\checkmark$ & $\checkmark$ \\
\hline
\end{tabular}

\section{Verilerin analizi}

Veri toplama aracı olarak kullanılan İIÇTT’nin uygulanması ile elde edilen veriler, içerik analizi yaklaşımı ile analiz edilmiştir. İçerik analizi, metinlerden oluşmuş bir küme içerisindeki belirli kelime ve kavramların belirlenmesine yönelik yapılmaktadır (Büyüköztürk vd., 2013). Öğrencilerin İIÇTT’ye verdikleri cevaplar içerisinde, informel istatistiksel çıkarsama teorik çerçevesinin bileşenleri olan verilerden delil, olasılıksal dil ve verilerin ötesinde genellemeler ile ilgili ifadeler tespit edilmiştir. Teorik çerçeve ile uyumlu cevapların belirlenebilmesi için literatürden yararlanılarak İnformel İstatistiksel Çıkarsama Tespit Formu (Bakınız Ek B) oluşturulmuştur. İIÇTT verilerinin analizi İnformel İstatistiksel Çıkarsama Tespit Formu yardımıyla, araştırmacı ve bir uzman tarafından yapılmıştır. Analiz sonrasında araştırmacı ve uzmanın kodlamaları birbiri ile karşılaştırılarak ortak olarak seçilen ifadeler tespit edilmiştir. Tablo 2'de informel istatistiksel çıkarsama bileşenleri ile uyumlu olan ve uyumlu olmayan ifadeler için örnekler verilmiştir.

Verilerin analizinde Tablo 2'deki bileşenlere uygun ifadeler olup olmama durumuna göre hareket edilmiş, bileșenlerin kendi içinde çok yeterli veya orta düzeyde yeterli gibi bir sınıflandırma yapılmamıştır. Herhangi bir soruya verilen cevapta teorik çerçevenin bileşenlerinin biri ile ilgili uygun bir ifade bulunması, analizde o öğrencinin o bileşen için yeterli seviyede olduğu şeklinde yorumlanmıştır. 
Marmara Üniversitesi Atatürk Eğitim Fakültesi Eğitim Bilimleri Dergisi / Journal of Educational Sciences

Yıl: Ocak $2017 \cdot$ Cilt-Sayı $45 \cdot$ ISSN: |300-8889 • ss. I-2I

Tablo 2

Informel Istatistiksel Çıkarsama Teorik Çerçevesi için Yeterli ve Yetersiz Ifade Örnekleri

\begin{tabular}{|c|c|c|}
\hline $\begin{array}{c}\text { Teorik Çerçevenin } \\
\text { Bileşenleri }\end{array}$ & Seviye & \multicolumn{1}{c|}{ Örnek İfadeler } \\
\hline \multirow{2}{*}{$\begin{array}{c}\text { Verilerin Ötesine } \\
\text { Genelleme }\end{array}$} & Yeterli & $\begin{array}{c}\text {...Yeni formülde çoğu kişinin } 40-80 \mathrm{dk} \text { aralığında baş ağrısı } \\
\text { geçmiştir, bu yüzden yeni formül kullanmak baş ağrısını geçirir... }\end{array}$ \\
\cline { 2 - 3 } & Yetersiz & ..Eski formülde iki kişinin baş ağrısı geçmiştir... \\
\hline
\end{tabular}

İIÇTT’nin birinci sorusuna verilen cevaplar yardımılla verilerin ötesine genelleme bileşeni için yeterli ve yetersiz ifade örnekleri verilmiştir. Verilerin ötesine genelleme bağlamında yeterli olan yukarıdakiörnekifadedeyeniformülünkıyaslandığıeskiformülegöredahaetkiliolduğuçıkarsaması yapılmıştır. Bu çıarsamanın içinde eldeki verilerin ötesine geçilerek tüm evren için bir genelleme yapılması söz konusudur. Yetersiz ifadede ise verilerin ötesine geçilmesi söz konusu olmamıştır.

\begin{tabular}{|l|l|l|}
\hline \multirow{2}{*}{ Verilerden Delil } & Yeterli & $\begin{array}{l}\text {..Çünkü yeni formüldeki insanların çoğunun } 80 \text { dakika içinde } \\
\text { ağrlları giderilmiştir... }\end{array}$ \\
\cline { 2 - 3 } & Yetersiz & ...Yeni formül daha çok işe yaramıştır... \\
\hline
\end{tabular}

İ̧̇TT’nin birinci sorusuna verilen cevaplar yardımıyla verilerden delil bileşeni için yeterli ve yetersiz ifade örnekleri verilmiştir. Verilerden delil bileşeni bağlamında yeterli olan örnek ifadede yeni formülün etkili olduğu çıkarsaması veriler kullanılarak desteklenmektedir. Yetersiz olan ifadede ise çıkarsama için bir gerekçe ortaya konmamıştır.

\begin{tabular}{|l|l|l|}
\hline \multirow{2}{*}{ Olasılıksal Dil } & Yeterli & $\begin{array}{l}\text {...Fakat daha da fazla verinin kaydının yapılması ile erkekler } \\
\text { geçebilir... }\end{array}$ \\
\cline { 2 - 3 } & Yetersiz & ...Erkekler devamsızlık yapmaya daha eğilimlidir... \\
\hline
\end{tabular}

İLÇTT’nin dördüncü sorusuna verilen cevaplar yardımıyla olasılıksal dil bileşeni için yeterli ve yetersiz ifade örnekleri verilmiştir. Olasılıksal dil bileşeni bağlamında yeterli olan ifadede cümlede belirsizlik yüklem olan 'geçebilir' kelimesi ile belirtilmiştir. Yetersiz ifadede ise cümlede bir belirsizlik ifadesi bulunmamaktadır.

\section{Bulgular}

Araştırmada elde edilen bulgular iki kısımda sunulacaktır. İlk olarak örneklemin tamamının merkezi eğilim ve yayllım ölçüleri konusunda informel istatistiksel çıkarsama teorik çerçevesinin ne şekilde yansıttığı genel olarak verilmeye çalışılacaktır. Genel durumun verilmesinin ardından ikinci kısımda, örneklem informel istatistiksel çıarsama teorik çerçevesinin bileşenlerine göre ayrı ayrı incelenecektir.

\section{informel istatistiksel çıkarsama teorik çerçevesindeki genel durum}

Örneklemin tamamının İIÇTT sonuçlarının, informel istatistiksel çıkarsama teorik çerçevesinin bileșenlerine göre analiz sonucu Tablo 3 'te sunulmuştur. 
Tablo 3

Yeterli ve Yetersiz Cevapların Teorik Çerçevenin Bileşenlerine Göre Dağılımı

\begin{tabular}{|c|c|c|c|}
\hline \multirow{2}{*}{ Örneklem } & \multicolumn{3}{|c|}{ İnformel İstatistiksel Çıkarsama Teorik Çerçevesi } \\
\cline { 2 - 4 } & Verilerin Ötesine Genelleme & Verilerden Delil & Olasllıksal Dil \\
\hline Yeterli & $19(\% 56)$ & $30(\% 88)$ & $23(\% 68)$ \\
\hline Yetersiz & $15(\% 44)$ & $4(\% 12)$ & $11(\% 32)$ \\
\hline
\end{tabular}

Örneklemin İIÇTT sonuçlarına bakıldığında ilk dikkati çeken nokta; teorik çerçevenin verilerden delil bileşeni bağlamında yeterli cevap verebilen öğrencilerin \%88'lik bir orana sahip olmasıdır. Buna göre öğrencilerin büyük bir kısmının, informel istatistiksel çıkarsamalarını verileri kullanarak desteklediklerini söylemek mümkündür. Verilerden delil bileşeninden sonra öğrencilerin en çok yeterli ifadeler kullanabildikleri bileşen \%68 ile olasılıksal dil bileşeni olmuştur. Öğrencilerin bu iki bileşende gösterdikleri başarıyı, verilerin ötesine genelleme bileşeninde kullanabildikleri söylenemez. Bununla birlikte öğrencilerin \%50'den fazlası verilerin ötesine genelleme bileșeni bağlamında yeterli ifadeler kullanabilmişlerdir.

Tablo 4

Yeterli Cevapların Informel İstatistiksel Çıkarsama Bileşenlerine Göre Dağılımı

\begin{tabular}{|c|c|c|c|}
\hline $\begin{array}{c}\text { Verilerin Ötesine } \\
\text { Genelleme }\end{array}$ & Verilerden Delil & Olasilıksal Dil & \\
\hline$\checkmark$ & $\checkmark$ & $\checkmark$ & $12(\% 35)$ \\
\hline- & $\checkmark$ & $\checkmark$ & $11(\% 32)$ \\
\hline$\checkmark$ & $\checkmark$ & - & $7(\% 21)$ \\
\hline- & - & - & $4(\% 12)$ \\
\hline $19(\% 56)$ & $30(\% 88)$ & $23(\% 68)$ & \\
\hline
\end{tabular}

Tablo 4, öğrencilerin yeterli cevaplarının teorik çerçevenin bileşenlerine dağılımını özetlemektedir. Dokuzuncu sınıf öğrencilerinin verdikleri cevaplarının Makar ve Rubin’in teorik çerçevesinin bileşenlerine göre yeterli ve yetersiz olma durumuna bakıldı̆̆ında öğrencilerin \%88'inin verilerden delil bileșenini kullanabildikleri görülmektedir. Aynı şekilde tablo incelendiğinde öğrencilerin \%56'sının verilerin ötesine genelleme yapabildikleri ve öğrencilerin \%68'inin de olasılıksal dil bileşenini kullanabildikleri ortaya çıkmaktadır. Öğrencilerin \%35’i İIÇTT’ye verdikleri cevaplarda informel istatistiksel çıkarsamanın üç alt bileşenini de yeterli şekilde kullanabilmişlerdir. Verilerin ötesine genelleme bileşeni bağlamında yetersiz cevaplar verirken; verilerden delil ve olasılıksal dil bileşenleri bağlamında yeterli cevaplar veren öğrenciler ise örneklemin \%32'sini oluşturmuştur. Örneklemin \% 21'ini oluşturan öğrenciler ise verilerin ötesine genelleme ve verilerden delil bileşenleri bağlamında yeterli cevaplar verebilmişken, olasılıksal dil bağlamında yetersiz cevaplar vermişlerdir. Son olarak öğrencilerin \%12'si, verilerin 
ötesine genelleme, verilerden delil ve olasılıksal dil bağlamının hiçbirinde de yeterli cevap verememiştir.

\section{Verilerin ötesine genelleme bileşenine ait bulgular}

Verilerin ötesine genelleme bileşenine ait bulgulara erişebilmek için IİÇTT'de birinci ve ikinci soru olmak üzere iki soru sorulmuştur. İÇTT’nin birinci sorusu şu şekildedir:

1) Meteoroloji Genel Müdürlüğü Merkezi hava tahminlerinin doğruluğunu belirlemek istemektedir. Bunun için daha önceden \%70 ihtimalle yağmur tahmini yaptıkları 300 günü tespit ederler. Bu 300 günün sonunda havanın gerçek durumuna bakarak tahminlerini karşılaştırırlar. Meteoroloji Genel Müdürlüğünün yaptığı tahminin çok doğru olarak kabul edilebilmesi için bu günlerin yüzde kaçında gerçekten yağmur yağmış olmalıdır? Seçtiğiniz şıkkı seçme gerekçenizi açılkayınız.

\section{( ) \%95 - \%100 ( ) \%85 - \%94 ( ) \%75 - \%84 ( ) \%65 - \%74 ( ) \%55 - \%64}

Soruda verilen veriler ışığında yola çıkıldığında ulaşılması gereken cevap \%65-\%74 aralığıdır. Doğru cevaptan ziyade bu soruda öğrencilerin informel istatistiksel çıkarsama yaparken verilerin ötesine genelleme bileşeni bağlamında neler ifade edebildikleri ortaya konmaya çalışılmıştır. Öğrencilerin \%21’i (7 kişi) bu soruya verdiği cevapta verilerin ötesine genelleme bileşenini kullanabilmiştir. Şekil 2'de, bu öğrencilerden birinin cevabı verilmiştir.

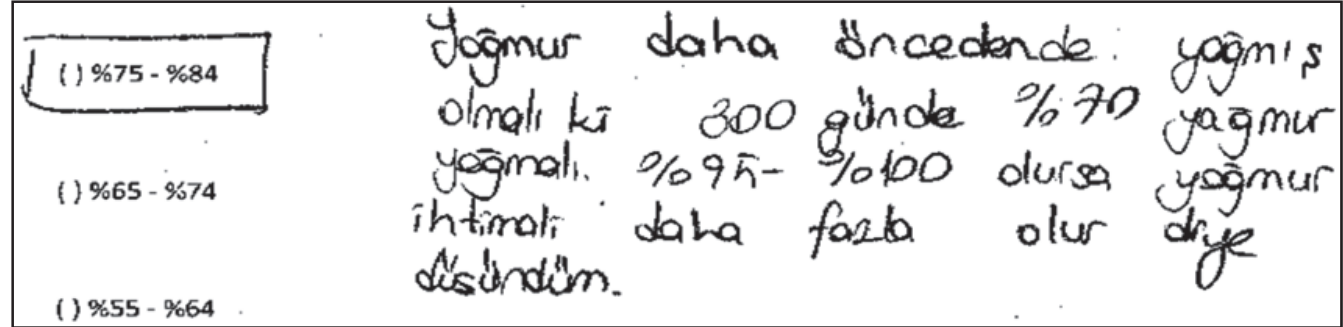

Şekil 2. Verilerin ötesine genelleme bileşeni bağlamında yeterli cevap

Öğrenci burada, soruda verilen 300 günün de ötesinde diğer günlerde de yağmur yağmasının gerekli olduğunu ifade etmiştir. 300 günün \%70'inde yağmur yağması tahminin çok doğru olarak kabul edilebilmesi için yeterli olacakken; burada öğrenci yılın kalan günlerinde de yağmurun yağmasının gerekli olduğu çıkarsamasını yapmıştır. Bu çıkarsamadan hareketle \%70'den daha fazla olacağı düşüncesi ile \%75-\% 84 seçeneğini işaretlemiştir.

Şekil 3’te ise verilerin ötesine genelleme bileşeni bağlamında yetersiz cevaplardan biri verilmiştir. Burada soruya verilen cevapta verilerin ötesine bir genellemeden söz etmek mümkün değildir. Öğrenci soruda verilen \%70 ihtimale dayanarak bu şıkkı seçtiğini belirtmiş, veriler hakkında yorum ve verilerin ötesine genellemede bulunmamıştır. 


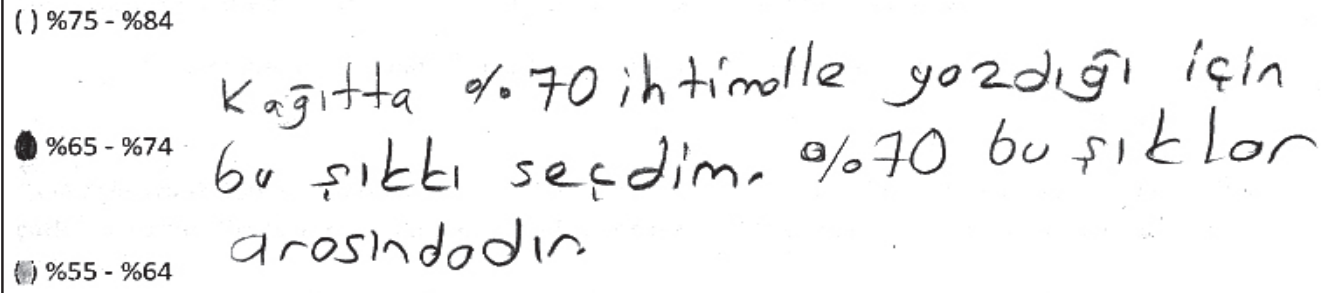

$\% 65-\% 74$$$
\text { Kagitta \% 70 ihtimolle yozdigl icin }
$$$$
\text { bu sikt secdim. } \% 70 \text { bu siklor }
$$

(1) $\% 55-\% 64$

Şekil 3. Verilerin ötesine genelleme bileşeni bağlamında yetersiz cevap

Verilerin ötesine genelleme bileșenine ait veri toplamayı hedefleyen İIÇTT’nin ikinci sorusu ise şu şekildedir:

2) Bir ilaç şirketi baş ağrısının tedavisi için yeni bir formül geliştirir. Bu yeni formülün etkisini test etmek için baş ağrısına sahip geniş bir hasta topluluğundan rastgele 250 kişi seçilir. $\mathrm{Bu}$ insanların başı ağrıdığı zaman 100 tanesine yeni formüle sahip ilaç; 150 tanesine ise eski formüle sahip ilaç verilir. Her bir hastanın baş ağrısının geçtiği zaman dakika olarak kaydedilir. Denemelerin sonuçları aşağıda gösterilmiştir:

Yeni Formül

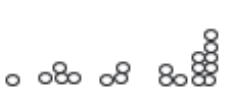

\section{Eski Formül}

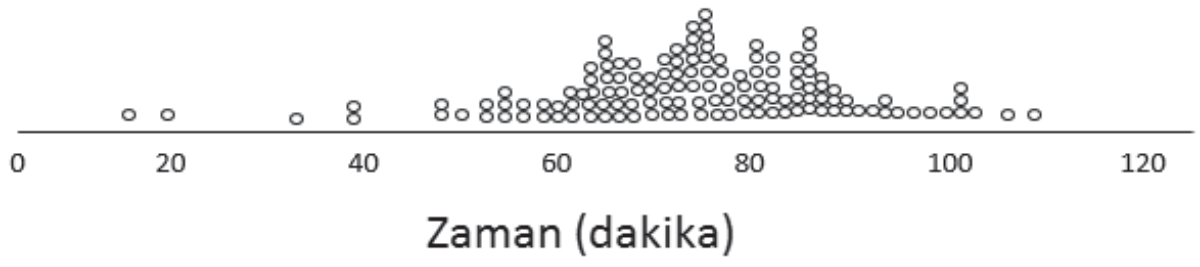

Buna göre aşağıdaki yorumun geçerli olup olmadığına karar veriniz. Seçtiğiniz şıkkı seçme gerekçenizi açıklayınız.

"Eski formül daha etkilidir. Eski formüle sahip ilaçtan alan iki kişinin 20 dakika içinde baş ağrıları geçmiştir; yeni formüle sahip ilaçta ise böyle bir durum yoktur. En kötü sonuç 120 dakika civart ile yeni formüle sahip ilaca aittir."
( ) Geçerli
( ) Geçerli Değil 
İIÇTT’nin ikinci sorusunda öğrencilerden verilerin ötesine geçerek bir genelleme yapmaları beklenmiştir. Öğrencilerin \%35’i (12 kişi) verdikleri cevaplarda, verilerin ötesine genelleme bileşeni bağlamında yeterli ifadeler kullanmıştır.

Şekil 4’te bu soruya verilen cevaplardan verilerin ötesine genelleme bileşeni bağlamında yeterli olan bir cevap örneği verilmiştir. Öğrenci verdiği cevapta verilerin ötesine giderek yeni formülün hastalığı daha kısa sürede tedavi edilmesine yardımcı olacağını savunmuştur.

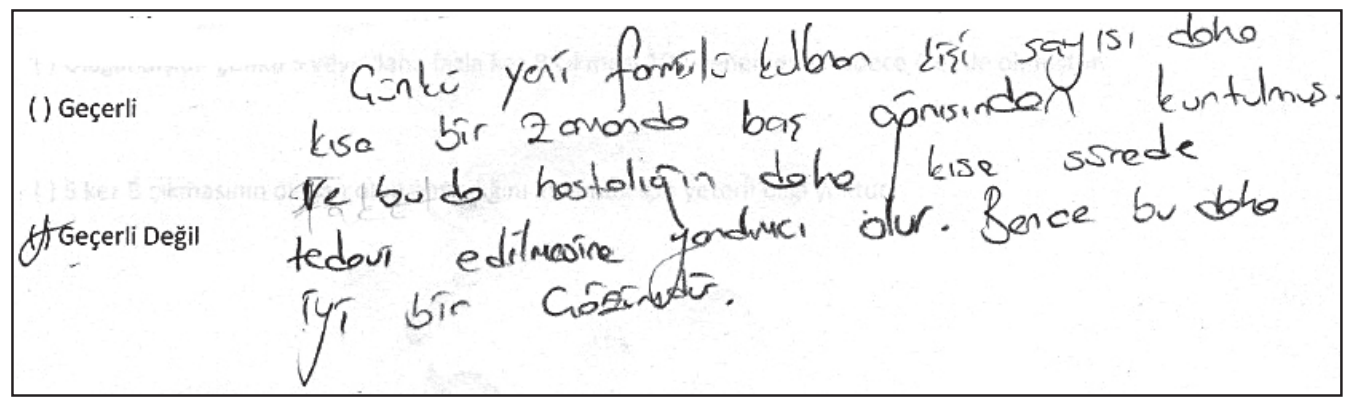

Şekil 4. Verilerin ötesine genelleme bileșeni bağlamında yeterli cevap

Şekil 5'te bu soruya verilen cevaplardan verilerin ötesine genelleme bağlamında yetersiz olan bir cevap örneği verilmiştir. Sadece sorudaki verileri göz önüne alarak verilen bu cevapta öğrenci, verilerin ötesine genelleme bileşeni bağlamında yetersiz bir cevap vermiştir.

\section{XGeçerli Değil Gegerti degit Guinki yeni formülde itoa etkisini daho kisa sirede göstermis.}

Şekil 5. Verilerin ötesine genelleme bileşeni bağlamında yetersiz cevap

\section{Verilerden delil bileşenine ait bulgular}

Verilerden delil bileşenine ait bulgulara erişebilmek için İ̇ÇTT'de ikinci, üçüncü ve dördüncü soru olmak üzere üç soru sorulmuştur. İ̧̇CTT’nin üçüncü sorusu şu şekildedir.

Bir istatistikçi harf çarkının doğru olup olmadığını test etmek için bir bilgisayar simülasyonu kullanıyor. Bilgisayar simülasyonu rastgele $\mathrm{A}, \mathrm{B}, \mathrm{C}$ ve $\mathrm{D}$ harflerini üretiyor. Denemenin her biri kendi içinde çarkın 10 kez döndürülmesinden oluşmak üzere bilgisayar simülasyonu 100 deneme gerçekleştiriyor. Daha sonra her $10^{\prime} \mathrm{lu}$

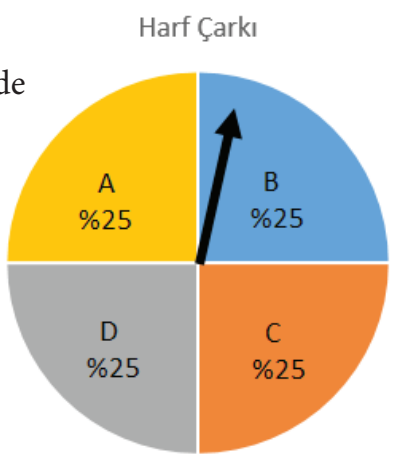


denemedeki B harfinin kaç tane olduğunu tespit ediyor.Örneğin; 1. Denemede: 3 kez A harfi, 2 kez B harfi, 4 kez C harfi ve 1 kez D harfi. 2. Denemede: 1 kez A harfi, 5 kez B harfi, 3 kez C harfi ve 1 kez D harfi....

Aşağıdaki grafik 100 denemenin her birindeki B harfi çıkma sayılarını göstermektedir. Buna göre harf çarkının 10 tur döndürülmesinin ardından 5 sefer B harfinin çıkmasının gözlemlenmesi hakkında ne söylenebilir?

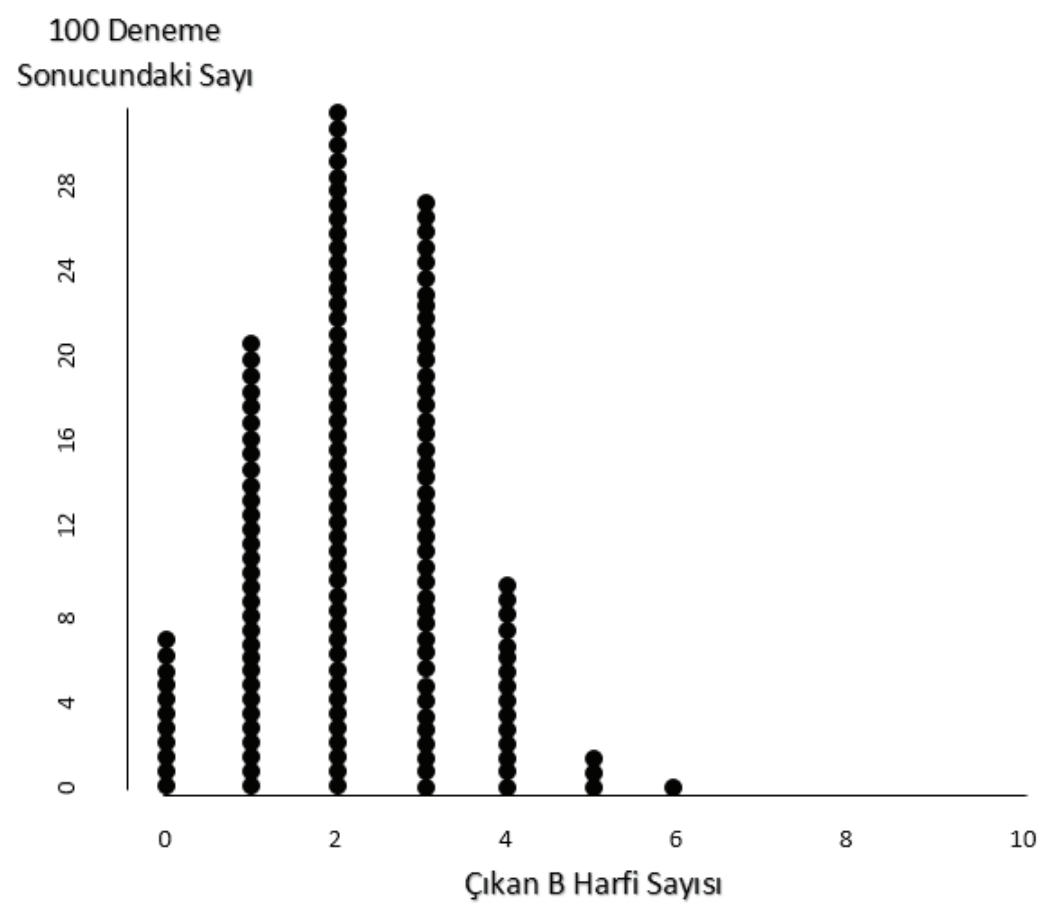

( ) Olağandır çünkü 100 denemenin 90’nında 5 veya daha az kez B harfi çıkmıştır.

( ) Olağandır çünkü 5 veya daha fazla kez B harfinin çıkması 100 denemenin 4'ünde olmuştur.

( ) Olağan dışıdır çünkü 5 kez B çıkması 100 denemenin 3’ünde olmuştur.

( ) Olağan dışıdır çünkü 5 veya daha fazla kez B çıması 100 denemenin sadece 4'ünde olmuştur.

( ) 5 kez B çıkmasının olağan olup olmadığını anlamak için yeterli bilgi yoktur.

İİÇTT'deki bu soru informel istatistiksel çıkarsama bileşenlerinden verilerden delil bileşeni ile ilgili veri toplama amacıyla sorulmuştur. Bu soruda öğrencilerden sorudaki verileri kullanarak çıkarsama yapmaları beklenmiştir. Sadece verilerden delil bileşeni ile ilgili veri toplama amacında olan bu soruya öğrencilerin \%38’si verilerden delil bileşeninde yeterli cevap verebilmiştir. 


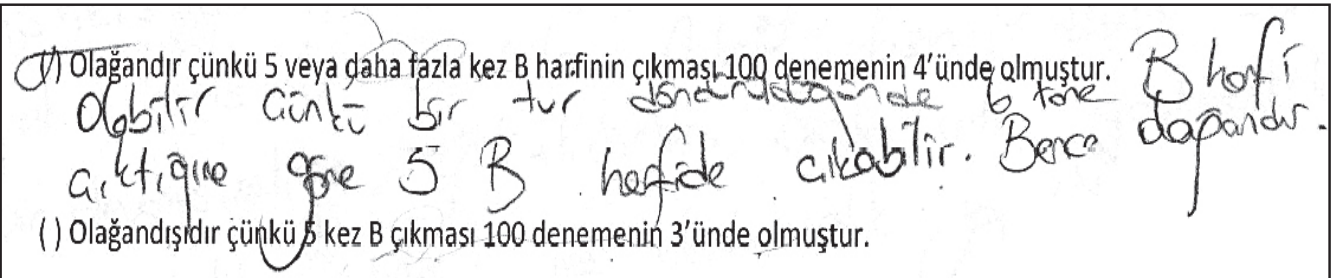

Şekil 6. Verilerden delil bileşeni bağlamında yeterli cevap

Şekil 6'da görüldüğü üzere, öğrenci vermiş olduğu cevabında 10 kez döndürme denemelerinden birinde 6 defa B harfinin çıkmış olduğu verisine dayanarak çıkarsamasını desteklemiştir. Soruya doğru cevap verememiş olmasına rağmen informel istatistiksel çıkarsamasında verilerden delil bileşenini yeterli bir şekilde kullandı̆̆ı söylenebilir.

İICTTT’nin verilerden delil bileşenine ait veri toplama amacında olan son sorusu ise şu şekildedir:

\begin{tabular}{|c|c|c|c|c|c|c|c|c|c|c|c|c|}
\hline \multicolumn{13}{|c|}{ DEVAMSIZLIKLAR } \\
\hline \multirow{2}{*}{ 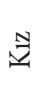 } & Ece & Ayşe & Esma & Dilek & Canan & İrem & Gül & Zeynep & Elif & Gülsün & Feyza & Berna \\
\hline & 6 & 8 & 10,5 & 10 & 11 & 10,5 & 4,5 & 4 & 7,5 & 10 & 10 & 8 \\
\hline \multirow{2}{*}{$\begin{array}{l}\frac{y}{2} \\
\frac{y}{y} \\
\text { yn }\end{array}$} & Ali & Can & Ata & Şen & Adem & Hakk1 & Sabri & Hayri & Şerif & Kemal & Osman & Erol \\
\hline & 8 & 8 & 7 & 8 & 8,5 & 6 & 6 & 8,5 & 8 & 7 & 6 & 19 \\
\hline
\end{tabular}

Tablodaki veriler bir sınıftaki kız ve erkek öğrencilerin bir yıl boyunca yaptıkları okul devamsızlıklarını göstermektedir. Bu verilere göre aşağıdaki soruları cevaplayınız.

- Kızların ve erkeklerin devamsızlıklarını nasıl karşılaştırırsınız?

- Verileri farklı bir şekilde düzenleyebilir misiniz? Düzenlemeyi nasıl yaptığınızı açıklayınız.

- Yaptığınız düzenlemeye göre kız ve erkeklerin devamsızlıklarını nasıl karşılaştırırsınız? Hangi öğrenci grubu devamsızlık yapmaya daha eğilimlidir? Bu kararı nasıl verdiğinizi açıklayınız.

Bu soruda 12 kız ve 12 erkek öğrencinin bir sene boyunca yaptıkları devamsızlıklara bakarak öğrencilerden kız ve erkek öğrenci grubunu devamsızlık eğilimleri bakımından karşılaştırmaları istenmiştir. Devamsızlığa kız öğrencilerin daha eğilimli olduğu sonucuna ulaşılması beklenen soruda öğrencilerin devamsızlıkları karşılaştırmada, verilerden delil bağlamında neler ifade edebildikleri ortaya konmaya çalışılmıştır. Öğrencilerin \%77’si verilerden delil bağlamında yeterli cevap verebilmişlerdir. 


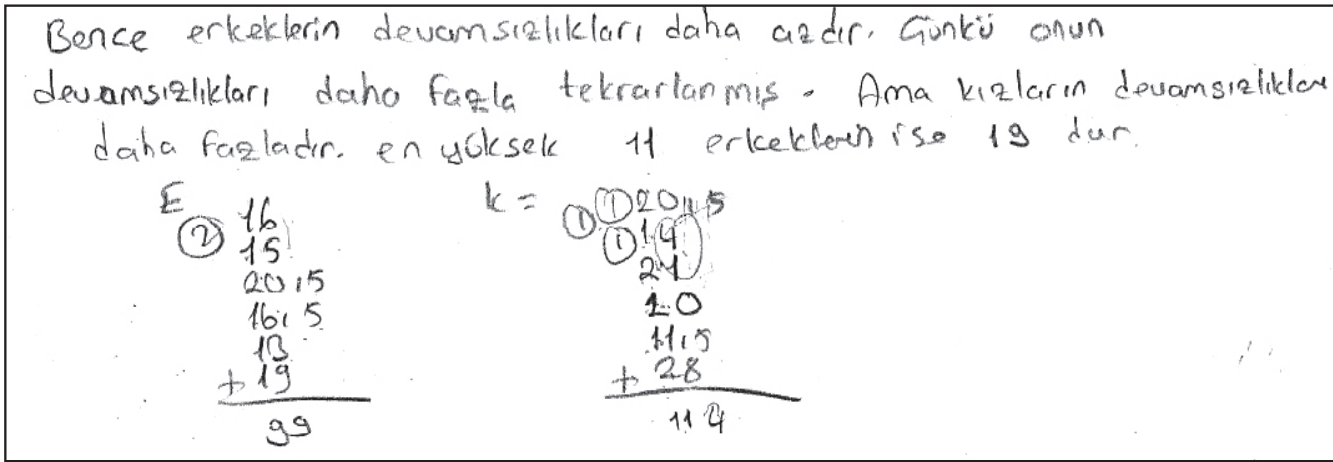

Şekil 7. Verilerden delil bileşeni bağlamında yeterli cevap

Şekil 7'de verilen öğrenci cevabında, öğrenci informel istatistiksel çıkarsamasını kız ve erkek öğrenci devamsızlıklarının en yüksek değerlerini delil olarak göstererek desteklemiştir. Kız öğrencilerin devamsızlıklarının daha fazla tekrarlandığını ifade ederek, merkezi eğilim ölçülerinden tepe değer kavramını informel olarak kullanmıştır.

Baktigimizda kiztar devamsizliga daha epilimlidir

Şekil 8. Verilerden delil bileşeni bağlamında yetersiz cevap

Şekil 8'de verilen öğrenci cevabında ise öğrenci verdiği cevap için herhangi bir delil ortaya koymamıştır. Sadece 'baktığımızda' demesi verdiği cevabını gerekçelendiremediği manasına gelmektedir. Bu sebeple verilerden delil bileșeni bağlamında yetersiz bir cevap olmuştur.

\section{Olasılıksal dil bileşenine ait bulgular}

İÇTT’nin birinci ve dördüncü sorusunda öğrencilerin olasıllksal dil bileşeni bağlamında neler ifade edilebildiği belirlenmeye çalışılmıştır. Öğrencilerin \%55,9'u birinci soruda olasılıksal dil bileşenini yeterli bir şekilde kullanabilmişlerdir. Dördüncü soruda ise bu oran $\% 32,4$ 'e gerilemiştir.

$\% 70$ e yokin yaĝmur tahminkeri yaptikkn iain
$\% 75-\% 84$. te yağmur yagmis olabilir.

Şekil 9. Olasılıksal dil bağlamında yeterli cevap 
Şekil 9'da İ̇ÇTT’nin birinci sorusuna verilen öğrenci cevabında, yüklem yani 'olabilir' kelimesi öğrencinin çıkarsamasında gömülü belirsizliğin ifadesi olmuştur. Öğrenci bu ifadesiyle olasilıksal dil bağlamında yeterli bir cevap vermiştir.

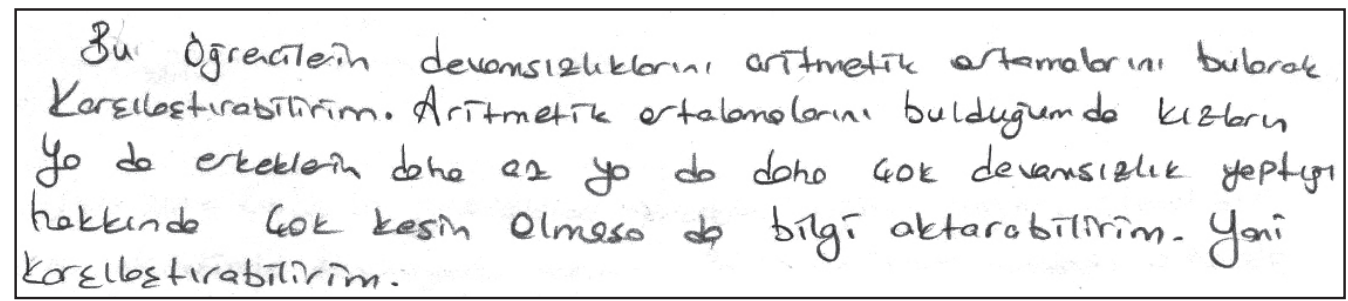

Şekil 10. Olasılıksal dil bağlamında yeterli cevap

İIÇTT’nin dördüncü sorusuna verilen Şekil 10'daki cevapta ise öğrenci kı ve erkek öğrencilerinin devamsızlıklarında verilerin çok kesin olmayan bilgi aktaracağından bahsetmektedir. Bu şekildeki ifadesiyle olasilıksal dil bileşenine vurguda bulunan öğrenci informel istatistiksel çıkarsamasının kesin olmadığını belirtmektedir. Bu da öğrencinin olasılıksal dili yeterli şekilde kullanabildiğini göstermektedir.

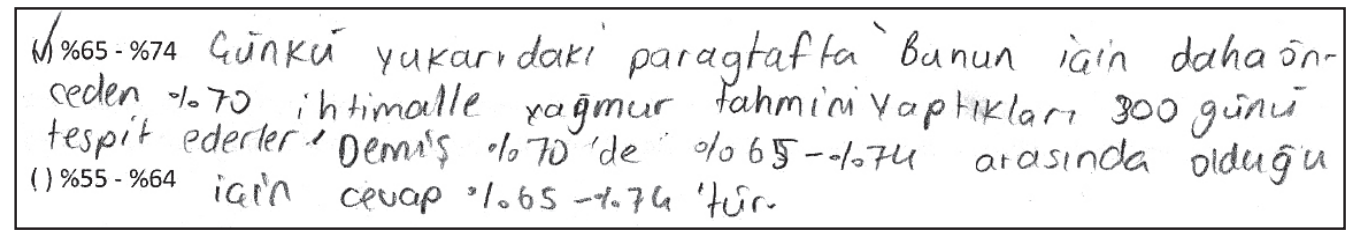

Şekil I I. Olasılıksal dil bağlamında yetersiz cevap

Şekil 11'deki cevapta ise öğrenci, olasılıksal dil bileşeni bağlamında kesin olmayan ifadeler kullanmak yerine cevabın \%70 olduğunu ifade etmiștir. Bu nedenle öğrencinin cevabı olasılıksal dil bağlamında yetersiz bir cevap olarak değerlendirilmiştir.

\section{Tartışma}

Dokuzuncu sınıf öğrencilerinin informel istatistiksel çıkarsamalarının nasıl olduğunu ortaya koyma amacında olan bu çalışmada, Makar ve Rubin'in (2009) informel istatistiksel çıkarsama teorik çerçevesi ışığında 34 öğrencinin İ̧̇CTT’ye verdikleri cevaplar incelenmiştir. Çalışmanın bulguları 9. sınıf öğrencilerinin çoğunluğunun (\%88) informel istatistiksel çıkarsama bileşenlerinden özellikle verilerden delil bileşenini kullanabildiklerini göstermiştir. Öğrencilerin verilerin ötesine genelleme ve olasılıksal dil bileşenlerindeki başarısı verilerden delil bileşenindeki başarıları kadar yüksek olmasa da öğrencilerin karşılaştıkları soruları cevaplarken 
informel çıkarımlar yapabilmelerinin önemli olduğu düşünüldüğünde (Franklin vd., 2007) bu öğrencilerin genel anlamda informel istatistiksel çıkarsama yapabilme noktasında iyi bir seviyede olduğu söylenebilir.

Makar ve diğerleri (2011) yaptıkları çalışmada, merkezi eğilim ölçülerinden tepe değer ve aritmetik ortalama kavramlarını öğrencilerin informel yollarla kullandıklarını gözlemlemişlerdir. Bu bulguya benzer şekilde bu çalışmada da, öğrencilerin informel olarak merkezi eğilim ölçülerini kullandıkları görülmüştür. Araştırmacılar, öğrencilerin formel kavramları öğrenmelerinden önce çıkarsamanın altında yatan informel anlayışın geliştirilmesini önermektedir (Weinberg, Wiesner ve Pfaff, 2010). Buradan hareketle informel yollarla merkezi eğilim ölçülerini kullanan öğrencilerin formel kavramları öğrenmeye hazır olduklarını söylemek mümkün olabilir. Buna paralel olarak çeşitli araştırmalarda, formel kavramların öğretiminden önce öğrencilerin muhakeme sürecinde informel çıkarsama yapmalarının formel eğitimleri için önemli olduğu ifade edilmektedir (Makar ve Rubin, 2009; Makar vd., 2011; Zieffler vd., 2008).

Paparistodemou ve Mavrotheris (2010), 9 yaş grubu ile yaptıkları çalışmada öğrencilerin gelişmiş çıkarımlar yapabildiklerini gözlemlemişlerdir. Bu durumun nedeninin bu öğrencilerin henüz okul müfredatının başında olmaları olabileceğini ifade etmişlerdir. Ayrıca çalışmada kullandıkları etkinliklerin ilgi çekici olmasının da gelişmiş çıkarımlar yapılmasını sağlamış olabileceğini belirtmişlerdir. Benzer şekilde 34 dokuzuncu sınıf öğrencisine uygulanan İICTTT sonucunda, öğrencilerin \%88'inin informel istatistiksel çıarsama yapabilmesini, bu öğrencilerin henüz merkezi eğilim ve yayılım ölçüleri konusunu görmemiş olmalarının sağladığ 1 söylenebilir. Ayrıca bu yüzdenin oluşmasına İ̧̇ÇT sorularının bağlamlarının neden olduğu da düşünülebilir. Özellikle İİÇTT’nin 1, 2 ve 4. sorularında öğrencilerden verdikleri cevapların nedenlerini açıklamaları istenmiştir. Bu durum öğrencileri informel istatistiksel çıkarsama yapmaya yönlendirmiş olabilir. Buna karşın soru içerisinde açıklama yapılması istenmediği halde öğrencilerin informel istatistiksel çıkarsama yaptıklarını görmek de mümkündür. Dolayısıyla soruların öğrencileri informel istatistiksel çıkarsamaya yönlendirdiğini söylemek pek mümkün değildir. Bununla birlikte Makar (2013), sorulardaki ayarlamalar sayesinde öğrencilerin tüm veri hakkında çıkarım yapmak için cesaretlendirilebileceğini ifade etmiştir. İIÇTT’deki birinci soruda “...Meteoroloji Genel Müdürlüğünün yaptığ tahminin çok doğru kabul edilebilmesi için bu günlerin yüzde kaçında gerçekten yağmur yağmış olmalıdır?” cümlesi yer almaktadır. $\mathrm{Bu}$ soru için verilen şıklarda tek bir yüzde yazmamaktadır. Şıklarda yüzdeler aralık olarak verilerek öğrencilerin çıkarsama için cesaretlendirildikleri söylenebilir. Sonuç olarak sorunun kökünde açıklama istenmesi çıkarsama için bir neden oluşturmayabilir. Ancak soru üzerinde yapılacak ayarlamalar öğrencileri tüm veri hakkında çıkarsama yapmada cesaretlendirebilir (Makar, 2013).

Öğrencilerin informel istatistiksel çıkarsamalarının içinde üstü kapalı bir biçimde formel tanımların geçmesi, araştırmada ortaya çıkan bir sonuçtur. Dokuzuncu sınıf öğrencilerinin merkezi eğilim ve yayılım ölçüleri konusunu görmeleri sene sonuna doğru gerçekleşmektedir (MEB, 2013). Araştırmada veriler eğitim ve öğretim yılının başında toplanmıştır. Dolayısıyla dokuzucu sınıf öğrencileri merkezi eğilim ve yayılım ölçüleri konusunu görmeden İICCTT’ye cevap vermişlerdir. Bununla birlikte öğrencilerden bir tanesi İ̇ÇTT’nin dördüncü sorusuna verdiği 
cevapta 'daha fazla tekrarlanmış' diyerek, merkezi eğilim ve yayılım ölçüleri konusundaki tepe değer kavramını informel olarak kullanmıștır. Tepe değerin ne olduğunu bilmemesine rağmen öğrenci bu soruya verdiği cevabı gerekçelendirmek için tepe değer kavramından yararlanmıştır. Önce konunun başlığının verilip sonra içinin doldurulmaya çalışıldığı istatistik öğretimine nazaran; kavramın zihinde oluşmasının ardından isminin konulması istatistik öğretiminde etkili olabilir. Makar (2013), informel istatistiksel çıkarsama yapan öğrencilerin kendi bağlamsal bilgilerini konu ile ilgili yollarla elde etme fırsatına sahip olduklarını ifade etmiş̧ir. Bu şekilde informel istatistiksel çıkarsama yapabilen öğrencilerin merkezi eğilim ve yayılım ölçüleri konusunu formel olarak öğrendikten sonraki istatistik öğretimi başarılarının araştırılması bu sonucun anlamlandırılmasına katkı sağlayabilir.

Pek çok araştırmacı, formel eğitimden önce öğrencilerin muhakeme sürecinde informel çıkarsama yapmalarının formel eğitimleri için yararlı olduğunu savunmaktadır (Makar ve Rubin, 2009; Makar vd., 2011; Zieffler vd., 2008). Bu çalışmada dokuzuncu sınıf öğrencilerinin büyük bir kısmının (\%88'inin) informel istatistiksel çıkarsama yapabildiği görülmüştür. İnformel istatistiksel çıarsama yapabilen bu öğrencilerin merkezi eğilim ve yayllım ölçüleri konusunun formel eğitiminde daha başarılı olmalarını beklemek mümkündür. Öte yandan PISA 2012 sonuçları göz önüne alındığında, geçmiş yıllara oranla ülkemizde gelişme olmasına rağmen, ülkemizdeki matematik başarısı OECD ülkeleri ortalamalarının altındadır (PISA, 2014). Bu durumun düzeltilebilmesi için informel istatistiksel çıarsama yapabilmeleri adına öğrencilere fırsatlar oluşturulması önerilebilir. Böylece informel istatistiksel çıkarsama yapabilen öğrencilerin muhakeme becerileri geliştirilebilir. Peki, öğrencilerin informel istatistiksel çıkarsama yapabilmesi için oluşturulabilecek firsatlar neler olabilir? Bu soruya cevap olarak, verilerin sadece sayılardan ibaret olmadı̆̆ı; saylların ötesinde çok daha derin anlamlar taşıdığını öğrencilerin anlaması sağlanabilir. Bunun sağlanabilmesi için öğrencilere verilen örneklerdeki problem durumunun ve verilerin öğrencileri düşünmeye sevk edici nitelikte olması önerilebilir. Bu çalışmada İ̧̇CTT’nin sorularındaki alt yapının kısa cevap türünden olmaması ve soruların öğrencileri muhakemeye yöneltmesi, öğrencilerin büyük bir kısmının informel istatistiksel çıkarsama yapabilmesini sağladığı söylenebilir. İnformel istatistiksel çıkarsama ve çlkarımsal muhakemeyi teşvik etmek için oluşturulabilecek firsatlardan birisi de bilgisayar destekli yaklaşımlar olabilir. Bu noktada ülkemizde istatistik öğretimi için tasarlanmış Türkçe eğitsel yazılımların ve etkinliklerin merkezi eğilim ve yayılım ölçülerinin öğretiminde kullanılması tavsiye edilebilir (Akkoç ve Yeşildere-İmre, 2005).

İnformel istatistiksel çıkarsama ve informel çıkarımsal muhakeme hakkında öğrencilerin kavrayışları ve muhakemeleri üzerinde daha fazla araştırmaya ihtiyaç vardır. Özellikle veri öğrenme alanının Ortaöğretim Matematik Dersi $(9,10,11$ ve 12. Sınıflar) Öğretim programına girmesi ile birlikte informel çıkarımsal muhakeme ve informel istatistiksel çıkarsama daha önemli bir konuma gelmiştir. Bu çalşsmada kullanılan informel istatistiksel çıarsama teorik çerçevesinin bileşenleri doğrultusunda farklı örneklemler kullanılarak öğrencilerin verilerin ötesine genelleme, verilerden delil gösterme ve olasılıksal dili kullanma becerileri araştırılabilir. Bu çalışmaların yanı sıra, matematik öğretmenlerinin merkezi eğilim ve yayılım ölçülerini sınıf ortamında nasıl öğrettikleri ve öğrencilerin informel çıkarımsal muhakeme ve informel istatistiksel çıkarsama becerilerini nasıl geliştirdiklerine dair araştırmalara da ihtiyaç olduğu düşünülmektedir. 


\section{Kaynaklar}

Aliaga, M., Cobb, G., Cuff, C., Garfield, J., Gould, R., Lock, R., Moore, T., Rossman, A., Stephenson, B., Utts, J., Velleman, P., Witmer, J. (2012). Guidelines for Assessment and Instruction in Statistics Education: College Report. Alexandria, VA: American Statistical Association.

Akkoç, H., Yeşildere-İmre, S. (2015). Teknolojik Alan Bilgisi Temelli Olasılık ve İstatistik Öğretimi. Ankara: Pegem Akademi.

Balcı, A. (2011). Sosyal Bilimlerde Araştırma Yöntem, Teknik ve İlkeler. Ankara: Pegem Akademi.

Ben-Zvi, D., Gil, E., Apel, N. (2007). What is hidden beyond the data? Helping young students to reason and argue about some wider universe. In D. Pratt \& J. Ainley (Eds.), Reasoning about Informal Inferential Statistical Reasoning: A collection of current research studies. Proceedings of the Fifth International Research Forum on Statistical Reasoning, Thinking, and Literacy (SRTL-5), University of Warwick, UK, August 11-17, 2007.

Büyüköztürk, Ş., Kılıç-Çakmak, E., Akgün, Ö. E., Karadeniz, Ş. ve Demirel, F. (2013). Bilimsel Araştırma Yöntemleri. Ankara: Pegem Akademi.

Cohen, L., Manion, L., Morrison, K. (2007). Research Methods in Education (6th ed.). New York: Routledge.

Franklin, C., Kader, G., Mewborn, D., Moreno, J., Peck, R., Perry, M., Scheaffer, R. (2007). Guidelines for Assessment and Instruction in Statistics Education (GAISE) Report: A Pre-K-12 Curriculum Framework. Alexandria, VA: American Statistical Association.

Garfield, J., Le, L., Zieffler, A., Ben-Zvi, D. (2015). Developing students' reasoning about samples and sampling variability as a path to expert statistical thinking. Educational Studies in Mathematics, $88,327-342$.

Gil, E., Ben-Zvi, Dani. ve Apel, N. (2008). Creativity in Learning to Reason Informally about Statistical Inference in Primary School. In Leikin, R., Proceedings of the 5th International Conference on Creativity in Mathematics and the Education of Gifted Students, (pp. 125-135). Haifa: Israel.

Koparan, T., Güven, B. (2013). A Study on The Differentiation Levels of Middle School Students' Statistical Thinking. Elementary Education Online, 12(1), 158-178.

Makar, K., Rubin, A. (2009). A framework for thinking about informal statistical inference. Statistics Education Research Journal, 8(1), 82-105.

Makar, K., Bakker, A., Ben-Zvi, D. (2011). The reasoning behind informal statistical inference. Mathematical Thinking and Learning, 13(1-2), 152-173.

Makar, K. (2013). Teaching Statistics using informal statistical inference. The Australian Mathematics Teacher, 69(4), 34-40.

MEB (2004). Milli Eğitim Bakanlığı, Talim ve Terbiye Kurulu Başkanlı̆̆ı, İlköğretim Matematik Dersi 1-5. Sinıflar Öğretim Programı. Ankara: MEB Yayınları.

MEB (2005). Milli Eğitim Bakanlı̆̆ı, Talim ve Terbiye Kurulu Başkanlığı, İlköğretim Matematik Dersi 6-8. Sinıflar Öğretim Programı. Ankara: MEB Yayınları.

MEB (2013). Milli Eğitim Bakanlığı, Talim ve Terbiye Kurulu Başkanlı̆̆ı, Ortaöğretim Matematik Dersi (9, 10, 11 ve 12. Sinıflar) Öğretim Programı. Ankara: MEB Yayınları.

MEB (2015). Milli Eğitim Bakanlığı, Talim ve Terbiye Kurulu Başkanlığı, İlkokul Matematik Dersi (1, 2, 3 ve 4. Sinıflar) Öğretim Programı. Ankara: MEB Yayınları.

Paparistodemou, E. ve Mavrotheris, M. (2010). Engaging Young Children in Informal Statistical Inference. C. Reading (Ed.) içinde, Proceedings of the 8th International Conference on Teaching Statistics (ICOTS 8) [CD-ROM]. Ljubljana, Slovenia, 11-16 July 2010. 
Park, J. (2012). Developing and Validating an Instrument to Measure College Students' Inferential Reasoning in Statistics: An Argument-Based Approach to Validation. (Unpublished doctoral dissertation). http://search.proquest.com/docview/1564044334 adresinden 5 Ekim 2014 tarihinde edinilmiştir.

Pfannkuch, M. (2006). Informal inferential reasoning. In A. Rossman \& B. Chance (Eds.), Working Cooperatively in Statistics Education. Proceedings of the Seventh International Conference on Teaching Statistics, Salvador, Brazil. [CDROM]. Voorburg, The Netherlands: International Statistical Institute.

Pfannkuch, M. (2007). Year 11 students' informal inferential reasoning: A case study about the interpretation of box plots. International Electronic Journal of Mathematics Education, 2(3), 149-167.

PISA (2014). PISA 2012 Technical Report, OECD.

Rossman, A. (2007, August). A statistician's view on the concept of inferential reasoning. Proceedings of the 5th International Research Forum on Statistical Reasoning, Thinking and Literacy (SRTL-5), University of Warwick, UK.

Rubin, A., Hammerman, J., \& Konold, C. (2006). Exploring informal inference with interactive visualization software. A. Rossman, \& B. Chance (Eds.), Proceedings of the Seventh International Conference on Teaching Statistics [CD-ROM]. Voorburg, The Netherlands: International Statistical Institute.

Rossman, A. (2008). Reasoning about informal statistical inference: One statistician's view (Accessed 10 March 2013). Statistics Education Research Journal, 7(2), 5-19. http://www.stat.auckland. ac.nz/ iase/serj/SERJ7(2) Rossman.pdf adresinden 5 Ekim 2014 tarihinde edinilmiştir.

Weinberg, A., Wiesner, E., Pfaff, T. J. (2010). Using Informal Inferential Reasoning to Develop Formal Concepts: Analyzing an Activity. Journal of Statistics Education Volume 18, Number 2.

Zieffler, A., Garfield, J., Delmas, R., Reading, C. (2008). A Framework to Support Research on Informal Inferential Reasoning. Statistics Education Research Journal: 7(2), 40-58. http://www.stat.auckland. ac.nz/serj adresinden 5 Ekim 2014 tarihinde edinilmiştir. 
